\title{
Śmierć króla i chustka Teodory
}

Historia ciał(a) w twórczości Zofii Nałkowskiej, opowiedziana przez badaczy i badaczki pisarstwa autorki Granicy ${ }^{\mathrm{I}}$, współtworzy „cielesny kanon” polskiej literatury pierwszej połowy XX w. Konteksty analiz utworów pisarki wyznaczane są przez kwestie modernistycznej świadomości płci, problematykę kobiecego autorstwa, twórczości i podmiotowości, oraz zagadnienia dotyczące literatury uwikłanej w najważniejsze, niejednokrotnie sprzeczne ze sobą psychologiczne, filozoficzne i społeczne „teorie tożsamościowe” ${ }^{2}$. Poniższy szkic, na który składają się interpretacje dwóch dzieł - Węzłów życia i Niecierpliwych, to propozycja spojrzenia na wybrane odsłony powieściowych figur, motywów, mikrozdarzeń, a także próba aktualizacji znaczeń kilku wątków istotnych dla rozumienia antropologii cielesności w pisarskim projekcie Nałkowskiej.

I W. Wójcik, Zofii Natkowskiej refleksje o starości, w: Starość, red. A. Nawarecki, A. Dziadek, Katowice 1995; E. Kraskowska, Piórem niewieścim. Z problemów prozy kobiecej dwudziestolecia międzywojennego, Poznań 1999; A. Górnicka-Boratyńska, Stańmy się sobą. Cztery projekty emancypacji 1863-1939, Warszawa 2002; A. Chałupnik, Sztandar ze spódnicy. Zapolska i Nałkowska: o kobiecym doświadczeniu ciała, Warszawa 2004; M. Marszałek, „Życie i papier”. Autobiograficzny projekt Zofii Nałkowskiej: Dzienniki 1899-1954, Kraków 2004; G. Borkowska, Antropologia ciała w zapiskach dziennikowych i publicystyce Zofii Nałkowskiej, w: Ucieleśnienia. Ciało w zwierciadle wspótczesnej bumanistyki. Myśl-praktyka - reprezentacja, red. A. Wieczorkiewicz, J. Bator, Warszawa 2007; M. Janowska, Postać, człowiek, charakter. Modernistyczna personologia w twórczości Zofii Natkowskiej, Kraków 2007.

${ }^{2}$ R. Nycz, Język modernizmu. Prolegomena bistorycznoliterackie, Wrocław 2002. 


\section{Ciała polityczne (Węzły życia)}

Gdyby centralnym tematem rozważań o Węzłach życia uczynić ciało, mogłoby to być ciało polityczne. Rozpisana przez autor$\mathrm{kę} \mathrm{z}$ rozmachem $\mathrm{w}$ pierwszych partiach powieści scena rautu ustawia dla tak sprofilowanego tematu wyraziste ramy. Wieloperspektywiczny opis przyjęcia, na którym bawi polska i międzynarodowa elita, pozwala narratorce na zarysowanie głównych problemów utworu, przede wszystkim tych związanych z klęską międzywojennej polityki kraju, który za chwilę ma przecież znaleźć się w stanie rozpętanej przez Hitlera wojny.

Inicjalne rozdziały książki stanowią także znaczący estetyczny węzeł podjętej tu narracji politycznej. Pisarka wprowadza nas na wystawną imprezę - na której gromadzą się zagraniczni ważni goście ubrani w szykowne wieczorowe stroje - wyzyskując charakterystyczne dla siebie rozwiązania pisarskie. Prezentuje więc postaci, sięgając po „fizjonomiczną syntezę" 4 , skrupulatnie rejestruje detale wyglądu, w tym także strojów ${ }^{5}$, odwołuje się do ludzko-zwierzęcych skojarzeń i porównań ${ }^{6}$. Wreszcie „postawa obserwacyjnej bierności” 7 sprawia, że granice narracyjnej niewiedzy, sygnalizowanej między innymi behawiorystyczną techniką opisu, zostają zatarte w miejscach ujawnień wszechwiedzącej narratorki ${ }^{8}$ :

Światło trzymało ludzi w ciągłym napięciu rzeczywistości, sztucznej rzeczywistości figur woskowych. Od włosa na głowie do połysku obuwia, każdy strzęp gronostaja czy sobola, każda nitka szychu

3 Z. Nałkowska, Węzly życia, w: eadem, Pisma reybrane, wybór, przedmowa W. Mach, t. 2, Warszawa 1956. Cytaty pochodzące z tego wydania powieści oznaczam dalej w nawiasie skrótem PW, po którym podaję numer tomu oraz numer strony.

4 „Miała staroświecką urodę francuskich miniatur - głowę osadzoną na długiej, szerszej ku dołowi szyi, oczy aż zbyt duże, okrągłe i brązowe, i usta wystające, małe jak jedna wiśnia” (PW, t. 2, s. 506).

5 „Wyglądali jak wszyscy inni tutaj, niczym się nie wyróżniali. On był wysokim starszym panem w generalskim płaszczu z bobrowym kołnierzem, ona miała na sobie wieczorowe jasne futro, a jej włosy ułożone jak fale i loki, były odsłonięte. I ona, jak inne, stanąwszy przed pałacem, zebrała w rękę wąski tren ze srebrnobzowej lamy. I ona, prowadzona za łokieć przez męża, spieszyła po schodach, przebierając drobnymi stopami w świecącej skórce" (PW, t. 2, s. 496).

${ }^{6}$ „Pomyślała, że Roman podobny jest do kraski - cały drobny, szarobłękitny i świecący. Aramowicz wyglądał przy nim niby duże, czarne, ciężkie zwierzę workowate" (PW, t. 2, s. 538).

7 Określenie E. Frąckowiak-Wiegandtowej, Sztuka powieściopisarska Zofii Natkowskiej (lata 1935-1954), Wrocław 1975.

${ }^{8}$ Ibidem. 
na sznurach i naszywkach wojskowych, każdy przelot lamy przez jedwab osnowy dał się widzieć z osobna, wyraźniejszy niż w żarze słonecznego południa. Uwięźli jak w magmie, poruszali się sztywno i sennie ruchami roślin głębokowodnych. Byli jakby wciąż gotowi zastygnąć w nieruchomość na samej krawędzi przywidzenia. (PW, t. 2, s. 504)

W ten sposób we wstępie do Węzłów życia można odnaleźć znaczenia kluczowych dla twórczości Zofii Nałkowskiej kategorii związanych z ciałem oraz cielesnością. Zainteresowanie fizjonomiką naprowadza nas na trop „lombrozjanizmu” pisarki ${ }^{9}$, ale też zdradza inspiracje naturalizmem ${ }^{\mathrm{Io}}$. Sondowanie szczegółów w powieściowych ujęciach postaci odsyła do kwestii dotyczących psychosomatycznej - niezwykle ważnej w twórczości autorki Granicy - kondycji człowieka ${ }^{\text {II }}$. $Z$ kolei rozmaite warianty animalizacji w tekstowych przedstawieniach ludzi pozostają zgodne z poglądem Nałkowskiej zakładającym relacyjność, czy nawet jedność świata zwierzęcego i człowieczego ${ }^{\mathrm{I} 2}$. Myślenie o zagadnieniach mających związek z ciałem politycznym w Węzłach życia należy, rzecz jasna, ulokować na przecięciu wszystkich wymienionych cielesnych odsłon pisarstwa i postawy egzystencjalnej pisarki.

Splot narracji politycznej $\mathrm{z}$ romansem - oczywisty oraz znakomicie sproblematyzowany w twórczości autorki Medalionów $w^{\mathrm{I} 3}$ - dostarcza wieloznacznego materiału do interpretacji. Prawdopodobnie najłatwiejsze byłoby wyróżnienie tych miejsc opowieści, w których Nałkowska umieszcza swoich bohaterów i swoje bohaterki w relacjach damsko-męskiej przemocy. Owe relacje mają polityczną strukturę, choćby w tym sensie, że rozmaicie dekonstruują związki pomiędzy tym, co prywatne, a tym, co publiczne. Wysokolski ma generalski honor, żonę i kochankę; obie kobiety funkcjonują za kulisami publicznej, politycznej działalności oficera i obie płacą za to wysoką cenę. Oprócz złożonych zależności zamkniętych $\mathrm{w}$ romansowej konstelacji, zazwyczaj reprodukującej strukturę przemocy, Nałkowska wskazuje niekiedy na wątki rodzinne - Dionizy Arcimowicz, czyli ojciec córki odtrąconej przez młodego Oxeńskiego, rozpoznaje siebie

9 E. Kraskowska, op.cit., s. 52.

ro G. Borkowska, op.cit., s. 90.

${ }^{\text {II }}$ M. Janowska, op.cit., s. 327-331.

${ }^{\text {I2 }}$ E. Frąckowiak-Wiegandtowa, op.cit., s. 70.

I3 I. Iwasiów, Powieść w obiegach. Lata osiemdziesiąte i kontynuacje, w: Prywatne/publiczne. Gatunki pisarstwa kobiecego, red. I. Iwasiów, Szczecin 2008, s. $153-156$. 
jako słabszego, a nawet przegranego w obowiązującym „układzie sił”, od którego zależą posady i urzędy. Lecz mikrowęzły władzy i zranienia to $\mathrm{w}$ omawianej powieści punkty zarazem newralgiczne, jak i stanowiące wierzchołki dodatkowych napięć ukrytych pod powierzchnią narracji. Autorka przez uwzględnianie pozornie nieważnych szczegółów dekonstruuje przyjęciowy blichtr, odsłaniając sieci najbardziej prywatnych kompleksów swoich bohaterów i bohaterek. Wówczas także międzyludzkie relacje ulegają erotyzacji.

Wróćmy do scen rautu. Wyjściowym dla czynionych tu przeze mnie dopisków uczyńmy cytowany powyżej fragment. Porównanie uczestników przyjęcia do figur woskowych stanowi symptom rzeczywistości pozornej, sztucznej; warto jednak przy tym prześledzić również dynamikę estetycznych perspektyw, obejmujących swym zasięgiem osobliwe "muzeum ludzkich ciał" ${ }^{4}$. W początkowych partiach Węzów życia narracyjne spojrzenie jest niezwykle zmienne, rozdysponowane pomiędzy najważniejszych bohaterów powieści. Najpierw widzimy stroje, szczegóły ubioru. Wbrew pozorom ich lista nie jest długa - futra, płaszcze, peleryny, suknie oraz fraki, i jeszcze informacje o rodzajach tkanin - welury, jedwabie (PW, t. 2, s. 496). Te ostatnie powiadamiają o wysokim statusie publicznym postaci, są etykietami klasy społecznej. Resztę z wymienianych części garderoby stanowią rekwizyty tyle ekskluzywne, ile powszechne, elitarnie unifikujące, zrównujące znakomitych gości w splendorze. „Elitarne ciała” w ujęciu Nałkowskiej są odziane dobrze, gustownie, ale bez ekstrawagancji i skandalu. W końcu - co wydaje mi się ważne w kontekście pytań o „polityczną anatomię" ${ }^{5}$ - ciałom, które obserwujemy, narratorka odbiera cielesność ${ }^{16}$.

Spośród postrzeganych narratorskim okiem - choć najczęściej za pośrednictwem głównych powieściowych postaci - tajemnic, nieporozumień, pretensji, które niekiedy w zupełnie nieoczekiwany sposób wiążą ze sobą losy Wysokolskich i Oxeńskich, sporo miejsca przypada tutaj naturze relacji młodego Oxeńskiego z matką. Kiedy Edmund spostrzega kobietę,

${ }^{1} 4$ Por. A. Wieczorkiewicz, Muzeum ludzkich ciat. Anatomia spojrzenia, Gdańsk 2000.

${ }_{5}$ Por. M. Foucault, Nadzorować i karać. Narodziny więzienia, przeł. T. Komendant, Warszawa 1998, s. 31.

${ }^{16}$ Krystyna Kłosińska w swojej książce poświęconej twórczości Garbieli Zapolskiej wspomina - za Rolandem Barthes'em - o „dwóch ubraniowych etykach”: „Pierwsza zakłada etykę osobowości i powagi, druga przeciwnie, etykę erotyzmu” (K. Kłosińska, Ciało, pożadanie, ubranie. O wczesnych powiesciach Gabrieli Zapolskiej, Kraków 1999, s. 247). Bezcielesne ciała, o których tu mowa, wpisywałyby się w „etykę osobowości”. 
możemy przypuszczać, że mamy do czynienia z jakąś historią miłosną. Tym razem Nałkowska to, co dotyczy rodziny, łączy z damsko-męskim flirtem, uzupełnia o erotyczne napięcie. Pani Chrudoszowa jest widziana przez swojego dorosłego już syna, wychowywanego wyłącznie przez ojca, w konwencji fabuły po freudowsku - kompleksowej oraz „rodzinnego romansu" ${ }^{17}$. Sceneria rautu sprzyja obu konwencjom - piękna, lecz niedostępna matka znajduje się w centrum męskiej rywalizacji o względy kobiety, a Oxeński kumuluje w sobie agresję wobec niej, skrywającą narcystyczne chłopięce pożądanie.

Poprowadzony przez Nałkowską w ten sposób wątek warto, jak sądzę, odnieść do innych rejonów powieści. Przestrzeń sali balowej i lustrzane ściany holu pozwalają na rozmaite kombinacje zbliżeń, zwłaszcza w sąsiedztwie jednego z nich historia Oxeńskich wydaje się pomniejszonym wariantem zdarzenia stricte politycznego. W końcu opisane w Węzłach życia przyjęcie odbywa się w cieniu ciała ważniejszego, bardziej centralnego - ciała niewidzialnego Józefa Piłsudskiego ${ }^{18}$, które, wiele na to wskazuje, w osobach państwowych dygnitarzy również wyzwala emocje związane z homospołecznym węzłem pragnień i bezsilności. Marszałka w powieści nie ma, lecz objawia się on w rozmowie Wysokolskiego i Arcimowicza. We wspomnieniu rozmówców Komendant tuż przed przewrotem majowym - niczym gemina persona ${ }^{\text {I9 }}$ - okazuje się dzielny i głęboko niedoskonały jednocześnie. Pali za dużo papierosów, pije zbyt dużo mocnej herbaty, mówi o swoim życiu jako niedokończonym projekcie. Nie odbiera mu to powagi. Szklanka w ręce przywódcy - jeśliby pamiętać o podwójnej cielesności majestatu - może być w tym przypadku rekwizytem utrwalającym autorytet. Gdy mowa o przywódcy - niedoskonałość nie rujnuje godności.

W utworze Nałkowskiej natrafiamy na ślady rytuału utrzymującego słabość ciała wodza w uniwersalnej mocy - w pamięci

${ }^{17}$ „Patrząc myślał zarazem ze złością, ża aż tak go obeszło niedawne spotkanie w przedsionku. Szło mu o tę kobietę, której podawał upuszczoną rękawiczkę. [...] Widział ją pośrodku jasnej przestrzeni z jakimiś mężczyznami - dużą, lekko wokół siebie okręconą [...]. I znowu go nie widziała! Patrzyła w inną stonę! Z czterech mężczyzn, którzy stali obok niej, jeden był jej mężem i co najmniej jeden kochankiem" (PW, t. 2, s. 514).

${ }^{18}$ E.H. Kantorowicz, Dwa Ciała Króla. Studium ze średniowiecznej teologii politycznej, przeł. M. Michalski, A. Krawiec, red. nauk. wyd. pol. J. Strzelczyk, Warszawa 2007. Do rozprawy Kantorowicza nawiązuje Jan Sowa w książce Fantomowe ciało króla. Peryferyjne zmagania z nowoczesna forma (Kraków 2011). Niniejszy artykuł został napisany przed ukazaniem się publikacji Sowy, dlatego nie nawiązuję tutaj do rozważań zawartych w tej publikacji.

I9 „Ludzki z natury, boski dzięki łasce”. Ibidem, s. 72 . 
Arcimowicza Piłsudski „ma w sobie coś z totemów, czczonych zwierząt hieratycznych, wspaniałe źrenice ptaka, profil świętego byka” (PW, t. 2, s. 531), a kwestie zwierzęcego, zwycięskiego instynktu, pieczętujące męską „łowiecką” wspólnotę, zostają przywołane kilkakrotnie. W takim symbolicznym otoczeniu przydomek „Dziadek” okazuje się dwuznaczną sygnaturą więzi, by tak rzec, plemiennej ${ }^{20}$. A ponieważ kontynuując opowieść, narratorka Węzłów życia prezentuje aluzyjną scenę, w której toczy się dyskusja o komplecie stołowym z herbem państwowym oraz „garniturze koronacyjnym” Augusta II, ta sama więź w innej odsłonie jawi się jako centralny wątek radykalnie fantazmatycznego rozdziału historii narodowych rojeń o dynastycznych tradycjach $^{2 I}$.

Wysnutą tu interpretacyjną fantasmagorię można uznać za możliwość opowieści podsuniętą przez fantasmagorię pisarską, co istotne, ponieważ Nałkowska tworzy polityczną narrację, odsłaniając zdarzenia przez własne uczestnictwo w nich i ich obserwację ${ }^{22}$. Na styk władzy, przemocy i pożądania nie zawsze doprowadza autorkę narratorska kalkulacja i nadświadomość; w Wezłach życia mamy do czynienia jednak z krytyką bezideowości polskiej elity po śmierci wodza, a w ramach powyższych hipotez dałoby się również uwypuklić motyw zapaści ciała społecznego $\mathrm{w}$ jeszcze innym kontekście.

Powieść Nałkowskiej to otwarta krytyka nie tylko sanacyjnego monarchizmu czy idei państwowości, która zostaje skonstruowana wokół nieistniejącego, „uśmierconego”, a wciąż pożądanego ciała króla. Ważniejsza warstwa powieści dotyczyć może iluzji politycznego egalitaryzmu, którą Nałkowska przedstawiła, komplikując kwestie związane z kluczową dla własnego pisarstwa kategorią osobowości²3.

Gdyby odwołać się do „politycznej historii” osobowości, którą prezentuje Richard Sennett w Upadku człowieka publicznego, a zatem pamiętać o jej nowoczesnym statusie definiowanym przez

${ }^{2}$ O innych literackich obliczach Piłsudskiego jako „Dziadka” pisze Włodzimierz Wójcik w książce Legenda Piłsudskiego w polskiej literaturze międzyrwojennej, Katowice 1986.

2I „To ten słynny «garnitur koronacyjny»! I jednemu z tutejszych znawców [...] udało się uzyskać ten komplet drogą wymiany. Taka zdobycz! Trzeba było widzieć ich miny! Zwłaszcza że dwór saski drze koty z «Wodzem»" (PW, t. 2, s. 533).

${ }_{22}$ Por. A. Galant, „Ja” $i$ bistoria, w: eadem, Prywatne, publiczne, autobiograficzne. O dziennikach i esejach Jana Lechonia, Zofii Natkowskiej, Marii Kuncewiczowej i Jerzego Stempowskiego, Warszawa 2010, s. 85-100.

${ }_{23}$ W. Bolecki, Pamięć - „choroba na śmierć” - świadomość („Niecierpliwi” Zofii Natkowskiej), „Pogranicza” 2003, nr 5, s. 23-30. 
wygląd zewnętrzny oraz opozycję spontaniczność - konwencja społeczna ${ }^{24}$, powieściowe sceny rautu dopełniałyby znacząco właściwą antropologicznemu projektowi pisarki problematykę tożsamościową ${ }^{25}$. Oto autorka odsłania znaczenia polityczne nie samej osobowości, lecz jej kłopotliwego statusu w życiu publicznym. W Węzłach życia Nałkowska rejestruje jeden $\mathrm{z}$ etapów upadku „ja” społecznego, o którym pisze również Sennett, zwracając uwagę na to, że upadek ów polega na dominacji psychologicznych symboli w obrębie życia społecznego i politycznego. Autorka zainteresowana semiotyką cielesnych wcieleń bohaterów swojej powieści szuka rys na elitarnie skrojonych figurach woskowych, rozpisuje spektakl cudzych spojrzeń nie po to, by odnaleźć autentyzm kryjący się za figurami manekinów, raczej aby stworzyć pomiędzy nimi miejsce na jakąkolwiek różnicę, podmiotową i ideową odmienność, która pozwalałaby dowieść, że „ludzie potrafią działać wspólnie, bez przymusu bycia takimi samymi” ${ }^{26}$.

Interesujące znaczenie zyskać mogą przy tym opisy fizjonomiki uczestników balu. Należą one do elementarza powieści realistycznej. Być może autorka Narcyzy nie okazuje się tutaj wyłącznie po prostu dłużniczką tradycji powieściowego realizmu, być może w jej estetycznych wyborach chodzi również o kolejny polityczny węzeł narracji - o „pospolitowanie tego, co elity uważały za swój przywilej” ${ }^{27}$, o napięcie pomiędzy estetycznym anachronizmem a narcystycznymi „obywatelskimi” projekcjami bohaterów Węłów życia? Zadaję to pytanie, myśląc o dalszym ciągu powieści Nałkowskej, w którym pisarka przedstawia także historię ciał, znajdujących się - można by rzec za Michelem Foucaultem, rozwijającym swoje rozważania w sąsiedztwie rozpozań Ernsta Kantorowicza ${ }^{28}-$ w „ciemnych zakątkach pola politycznego" ucieleśnianej/odcieleśnianej władzy. Ów ciąg dalszy pozwala na dopisanie niewielkiego, ale chyba koniecznego

${ }^{24}$ „Osobowość stworzona przez cechy zewnętrzne, kontrolowana - jeśli w ogóle - przez świadomość przeszłości danej osoby, spontaniczna tylko wtedy, gdy odbiega od normy: te nowe kategorie osobowości weszły do użytku w ubiegłym stuleciu, by interpretować samo społeczeństwo jako zbiór osobowości. W takim właśnie ogólnym kontekście osobowość wkroczyła do publicznej sfery stolicy". R. Sennett, Upadek człowieka publicznego, przeł. H. Jankowska, Warszawa 2009, s. 253.

${ }_{25}$ M. Marszałek, Podmiotowość i literatura: o psychologicznej „teorii tożsamości” w prozie Zofii Natkowskiej, w: eadem, op.cit., s. 69-87.

${ }^{26}$ R. Sennett, op.cit., s. 415.

${ }_{27}$ J. Bachórz, Karta z dziejów zdrowego rozsądku, czyli o fizjonomice w literaturze, „Teksty” 1976, nr 2, s. 101.

${ }^{28}$ M. Foucault, op.cit., s. 29. 
suplementu do historycznoliterackiej opowieści o powojennym pisarstwie Zofii Nałkowskiej ${ }^{29}$.

Katarzyna, żona prokuratora, córka oficera, kochanka ideowca, cierpi - wiele na to wskazuje - na zaburzenia łaknienia lub po prostu na bulimię ${ }^{30}$. Cyngal, węzien polityczny, choruje na gruźlicę, umierający wrasta w szpitalną celę. Honorata, kochanka Wysokolskiego, podejmuje próbę samobójczą, powody zostają niedopowiedziane, lecz chodzić może o odtrącenie i aborcję. Oxeński umiera na udar mózgu, ale też na wyrzuty sumienia. W końcu z początkiem wojennych nalotów bohaterki Węztów życia w piwnicach, schronach spotykają stare - schorowane, niedosłyszące, niedołężne - kobiety, opuszczone, bez opieki, zmuszone radzić sobie w ekstremalnej sytuacji. Centrum historii wszystkich tych ciał stanowi zazwyczaj fizjologia. W związku z rozważaniami poczynionymi wcześniej, dotyczącymi ciała władzy i rytuału, można by powiedzieć, że wszystkie „inne” ciała są przede wszystkim niezwykle fizjologiczne, ponieważ nie istnieją dla nich żadne doniosłe publiczne ryty.

W ramach narracji politycznej Nałkowskiej, zarówno „wyzwolicielskiej” (kobiecej, emancypacyjnej), jak i „kryzysowej” (społecznej, diagnozującej), w prezentacji ciała bohaterów i bohaterek, nawet jeśli chodzi o cielesną wolność, fundamentalna okazuje się cielesna kruchość. Nie jestem pewna, czy „kruchość” to adekwatne określenie, czy nie jest zbyt trywialne, obok niego wypisałabym więc jeszcze: łamliwość, ranliwość, bezbronność. Mają one w twórczości Nałkowskiej wymiar podstawowy, są niejako przed wolnością. Zatem fakt, że narratorka towarzyszy swoim postaciom $\mathrm{w}$ fizjologii, okazuje się z jednej strony śladem

${ }^{29}$ „Węzły życia kontynuują - zwłaszcza w pierwszej części - ów [obecny w Niecierpliweych - A.G.] eksperyment artystyczny. Kto wie, jak rozwijałaby się proza Zofii Nałkowskiej, gdyby wojna nie zakłóciła naturalnego rytmu procesów twórczych i na czas pewien nie zdewaluowała wartości wszelkich eksperymentów formalnych w sztuce? O okropnościach wojny można było mówić tylko jak najprościej, językiem artystycznym, lecz wyzbytym wszelkiej sztuczności, wolnym od wyrafinowanych technik i zabiegów. I tak punktem dojścia tej twórczości stała się wstrząsająca prostota Medalionów”. E. Kraskowska, op.cit., s. 71.

$3^{\circ}$ „Tajemnice Katarzyny są niepoważne. Miała zwyczaj nic nie jeść, gdy na nią patrzono, jakby jedzenie było czymś wstydliwym. [...] Można ją było jednak zastać niekiedy samą, gryzącą różne przysmaki - czekoladki, kasztany, jakiś zjełczały tortowy trójkącik, kandyzowane owoce, thustą guzowatą chałwę, krem z przedwczorajszego deseru. Chowała te smakołyki nie w kredensie, tylko w szufladzie małej komódki $\mathrm{z}$ różanego drzewa, gdzie trzymała także różne koronki i wstążeczki. Tak zaskoczona, robiła wrażenie zwierzątka, które pożera wydobytą z piasku kość, zagrzebaną tam wprzódy w sekrecie przed oczyma ludzi” (PW, t. 2, s. 609). 
współuczestnictwa $\mathrm{w}$ mięsności kondycji ludzkiej ${ }^{3 \mathrm{x}}$, z drugiej zaś - poświadcza pisarską próbę materializacji bólu i zranienia. To jednak nie wszystko.

Autorka opisuje ciała cierpiące w samotności, ale są to też ciała bez duszy, bez duszy w tym sensie, że nie mieszczą się w symbolicznych, wspólnotowych rytuałach, nie posiadają także żadnych transcedentalnych protez, które mogą nadać im godność. Próba literackich zbliżeń do fizjologii ciał chorych, kalekich, starzejących się to w przypadku twórczości Nałkowskiej coś więcej niż pochylanie się nad słabymi, wykluczonymi. Najistotniejsze w jej pisaniu jest ujęcie? przedstawienie? stwarzanie? godności „ciał świeckich" ${ }^{2}$.

\section{Ciała graniczne (Niecierpliwi)}

Biologizm w Nieciepliweych ${ }^{33}$ ma niewiele wspólnego, jak powiada jedna ze znakomitych interpretatorek utworu ${ }^{34}$, z naturalistyczym determinizmem, „w perspektywie schopenhauerowskiej czy stoickiej ów - tak mocno zarysowany w powieści - biologizm staje się metaforą przemijalności człowieka i zupełnie traci swój anachroniczny, naturalistyczny charakter" ${ }^{35}$. W powojennych i najnowszych omówieniach książki opublikowanej w roku 1939 badaczki i badacze zdecydowanie podkreślają egzystencjalistyczne, odległe od determinizmu, uzasadnienia tego, co wiąże się z myśleniem Nałkowskiej o cielesności i biologiczności ludzkiej kondycji. Zarysowane w ten sposób stanowiska okazują się polemiczne wobec wcześniejszej krytyki, która Niecierpliweych uznała za utwór nieudany i nudny ${ }^{36}$, a zarazem umożliwiają dowartościowanie dokonania Nałkowskiej przez umieszczenie go w kontekście XX-wiecznych europejskich nowatorskich realizacji powieściowych, głównie tych spod znaku twórczości Fran-

${ }^{3^{I}}$ „W dziele Nałkowskiej [...] mięsność - stanowi podstawę więzi wspólnotowej”. G. Borkowska, op.cit., s. 99.

$3^{2} \mathrm{O}$ etycznych koncepcjach „świeckiej godności” pisze W. Chańska w książce Nieszczęsny dar życia. Filozofia $i$ etyka jakości życia w medycynie wspótczesnej (Wrocław 2009). Pojęcie „świeckiej godności” jest tutaj o tyle ważne, że w kulturze europejskiej źródło „godności” bije w języku teologii. Por. E.H. Kantorowicz, op.cit., s. 13.

33 Z. Nałkowska, Niecierpliwi, wstęp i oprac. K. Jakowska, Kraków 2001. Cytaty pochodzące $\mathrm{z}$ tego wydania powieści oznaczam dalej w nawiasie skrótem $\mathrm{N}$, po którym podaję numer strony.

${ }_{34}$ K. Jakowska, „Ta najdziwoniejsza zjej ksiązek”, w: Z. Nałkowska, Niecierpliwi, op.cit., s. 5-45.

35 Ibidem, s. 23.

${ }^{36}$ Ibidem, s. 6-8. 
za Kafki37. Dzięki owym odczytaniom dzisiejsza lektura Niecierpliwych to lektura niedocenionego literackiego eksperymentu oraz tekstu będącego prawdziwą summą , antropotanatologii" ${ }^{8}$ pisarki.

Odszukiwanie historii ciał(a), która została wpisana w tę powieść, nie może zatem odbywać się poza horyzontem tanatycznej wyobraźni Nałkowskiej39. Jesteśmy w środku opowieści, której narracja nieśpiesznie, choć niekiedy skutecznie kumulując czytelniczy niepokój, asystuje bohaterkom i bohaterom $\mathrm{w}$ radzeniu sobie ze świadomością śmiertelności, w umieraniu, w końcu także w zbrodni. Jednocześnie rozpoczęcie interpretacji Niecierpliweych właśnie od końca umożliwia dostrzeżenie błahego, melodramatycznego zaplecza doniosłej paraboli, którą - zdaniem większości badaczy i badaczek - pisarka swoją powieścią zbudowała. W moim przekonaniu zaplecze to jest raczej gorzką i po nietzscheańsku tragiczną kpiną z tropienia parabolicznych sensów losu powieściowych bohaterów - oto jedna z hipotez inicjujących moje rozważania.

Jak powiada Hanna Kirchner - centralną świadomością utworu jest Jakub ${ }^{40}$. Znamienny to jednak fakt, że jego pozycja nie jest centralna od razu, jego introspekcje zagarniają coraz więcej miejsc narracji, sukcesywnie wypełniają i zarażają neurotycznymi stanami i wizjami kolejne partie tekstu, by w finale powieści Jakub mógł wystąpić w roli tego, który rozstrzyga o życiu własnym i Teodory. Ta narracyjna zachłanność bohatera wydaje mi się niezwykle ważna. Gdy umiejscowimy go w centrum Niecierpliwych, pozostanie człowiekiem przede wszystkim zrozpaczonym; tymczasem psychiczna i emocjonalna zapaść Jakuba rozwija się, narasta i nawarstwia. Mamy do czynienia z postacią zakompleksioną, niepewną, przewrażliwioną i poranioną, lecz i ekspansywnie wyalienowaną. W powieści odnajdziemy kilka scen powiadamiających, że pod piórem Nałkowskiej los młodego Mrowy daje się ułożyć tyle w opowieść o totalnej rozpaczy, ile

37 M. Głowiński, Porządek, chaos, znaczenie. Szkice o powieści wspótczesnej, Warszawa 1968.

${ }^{8} 8$ B. Smoleń, Pteć i śmierć. Tanatyczna reyobraźnia Zofii Natkoweskiej, w: Ciało, pteć, literatura, red. M. Hornung, M. Jędrzejczak, T. Korsak, Warszawa 2001, s. 229. Za kulminację stwarzanej przez pisarkę antropotanatologii Smoleń uznaje postać Celiny Bełskiej z Domu kobiet, jednak podsumowując swoje rozważania, badaczka stwierdza: „Wszystko, z czego zbudowani zostaną Niecierpliwi, jest już gotowe, obmyślone i wypracowane, [...] i nic nie przeszkadza, by zostało teraz uogólnione w powieści o «rodzie samobójców» i wypowiedziane przez Jakuba" (ibidem).

39 M. Janion, Otwarcie depozytów. Z prof. Maria Janion rozmawia Stawomir Buryta, w: eadem, Ptacz generała. Eseje o wojnie, Warszawa 1998, s. 276.

$4^{\circ}$ H. Kirchner, Natkowska albo życie pisane, Warszawa 2011, s. 488. 
w wymagającą namysłu historię zuchwałości, a nawet przemocy. Co istotne - dla tej przemocy chyba nikt oprócz głównego bohatera nie odnajduje „metafizycznych” objaśnień.

Poza fragmentami, w których Jakub okazuje się zazdrosny i zaborczy $\mathrm{w}$ stosunku do Teodory, poza kolekcjonowaniem w samotności ran z przeszłości, bywa on wręcz - mimo wzbudzającego współczucie smutku - megalomańsko obolały. Kiedy umiera Marta, wszyscy przy tym umieraniu są w szczególny sposób obecni: czuwają wspólnie, rozmawiają szeptem, wymieniają się czułością, istnieją wobec siebie. Mrowa „myśli o sobie, choć to nie on umiera" (N, s. 147), dla niego śmierć Marty „odbywa się jakby bezosobowo” (N, s. 146). Teodora patrzy na jej „wyostrzoną w półświetle twarz” (N, s. 146), widzi „wąskie usta” (N, s. 146), Jakub zaś - „podziemny dół, ciemność, trumnę" (N, s. 147). Innym razem, na wieść o obłędzie męża Hortensji, bohater zdobywa się na samotną abstrakcyjną refleksję, gdy tymczasem kobiety muszą zająć się chorym, przezwyciężyć lęk, podjąć decyzję o hospitalizacji. W Niecierpliweych obłęd, wobec którego bohaterki muszą się odnaleźć, jest ludzki, to po prostu błąd, przez który się cierpi (N, s. 145). Jakub - jako świadek wszystkiego z oddalenia - nie dotyka choroby. Nie mam pewności, czy - jak powiadają badaczki twórczości Nałkowskiej Mrowę dręczy brak dystansu, nadmiar wrażliwości, poczucia winy i odpowiedzialności ${ }^{1 \mathrm{I}}$, czy też może nadmiar narcystycznego samoudręczenia. Bohater Niecierpliweych przeżywa, myśli, rozrasta się od środka; ostatecznie granic rzeczywistości, którą rejestruje, nie sposób oddzielić od granic, w których zamyka się sam z własną rozpaczą. Podkreślam ów wątek nie w celu licytowania psychologicznych diagnoz - sądzę raczej, że po wypowiedzeniu tych wątpliwości i niejasności wyraźniejsze stają się zarówno dwuznaczność powieściowej kreacji Jakuba, jak i antyparaboliczna wymowa utworu autorki Narcyzy.

To ciekawe i zastanawiające, że w rozpisanym przez Nałkowską świecie powieści jesteśmy skłonni przyglądać się Jakubowi Mrowie jako głównemu autorowi zawartego w Niecierpliweych literackiego traktatu o śmierci, marginalizując to, co mówią nam o śmierci i byciu wobec niej inne postaci. Poza opowieścią przyszłego zabójcy istnieje przecież tutaj także inny tekst o umieraniu, tekst nieciągły, wzmiankowany, nawet jeśli wyznaczony jako osobne rozdziały książki - jakby dygresyjny, pokazujący powierzchnię rzeczy. Na jego zawartość składają się informacje o trupach noworodków, żałobie matek, udanych i nieuda-

${ }_{4 \mathrm{I}}$ K. Jakowska, op.cit., s. 16; H. Kirchner, op.cit., s. 488-490. 
nych samobójstwach, odnajdujemy tu także „zlęknioną i chorą" Leonię, która „omawia” swoją chorobę z Teodorą, i Martę czekającą na śmierć, która „zna sprawę”. W rozdziale Stypa obserwujemy z kolei obraz zbiorowego, nieco żenującego, nieco przerażającego, rytuału okołopogrzebowego. Ów inny tekst wydaje się poboczny wobec autoanaliz Jakuba, a jednak obecny w nim ładunek bólu i cierpienia nie okazuje się mniejszy, błahszy, mniej ważny. Czy nie jesteśmy po stronie Jakuba dlatego, że chcemy, wolimy być - tak jak on - sensowni, gdy tymczasem Nałkowska Niecierplireymi opowiada nam raczej o tym, że świat bez nas - zwyczajnie i niezwyczajnie - jest możliwy, że jesteśmy bardziej przypadkowi niż uzasadnieni?

Różnica pomiędzy tym, co o granicach życia mówi do nas Mrowa, a tym, czego dowiadujemy się z pozoru marginalnych historii, jest jednak, w moim przekonaniu, znacząca. W drugim przypadku mamy do czynienia z olbrzymim ludzkim strachem, ale przede wszystkim jeśli nie $\mathrm{z}$ oswajaniem śmierci (bo w ujęciu Nałkowskiej nigdy nie przestaje ona być egzystencjalnie nieoswajalna), to przystawaniem na jej bytowy charakter, status, na taką jej dyspozycję. Dla Jakuba śmierć jest natomiast czymś nieustannie skandalicznym, co więcej - w jego pojęciu wymaga ona kolejnych poziomów emocji i argumentacji, wyjaśnień i intelektualnych spekulacji. Jego obsesyjne przywiązanie do rodziny, nieprzerwane drążenie przyczyn wiszącej nad wszystkimi rodzinnej klątwy przypomina szukanie rodowodu śmiertelności, próbę usensowienia za wszelką cenę nieuchronności umierania.

Dystynkcję, o której tu mowa, można dodatkowo wyjaśnić w następujący sposób: w tych przestrzeniach narracji, do których nie sięga Jakubowe ego, autorka odsłania przed nami sytuacje bycia wobec śmierci z fenomenologiczną naocznością, jako zdarzenia same w sobie, jako „przystawanie na to, co się robi samo" (N, s. 76). Kiedy w powieści głos zabiera Mrowa, dostęp do doświadczenia okazuje się - czego najlepszym dowodem jest rozdział Sumienie, w którym obserwujemy, jak bohater „wytwarza" w sobie poczucie winy ${ }^{42}$ - konstruowany, a w konsekwencji w wierzchniej warstwie opowieści daje się odczytać jako uniwersalna egzystencjalistyczna przenośnia, w planie psychologicznym zaś, umożliwiającym wgląd w świadomość bohatera, przypomina objawy choroby.

$4^{2} \mathrm{~W}$ innym miejscu powieści odnajdujemy taki fragment: „Teodora była taka sama, jak te dziewczęta z parku. Widocznie wtedy jeszcze za wcześnie było, aby w to wejść, widocznie coś wewnątrz niej musiało się na to przygotować. Nie udawała nic. To Jakub interpretował sobie źle jej lękliwość, to on przenosił tę pospolitą sprawę w inny wymiar” (N, s. 101). 
Granicą dla istniejących w Niecierpliweych obu narracji o śmierci jest ciało. Gdy narratorka nie oddaje ciał powieściowych postaci spojrzeniu Jakuba, zbliża się do owej granicy na rozmaite sposoby. Interesujące zastosowanie ma tutaj opis fizjonomii poszczególnych bohaterów - nie służy on charakterologicznej prezentacji, w niezwykle płynnym świecie powieści pozwala za to oznaczać zasadniczą odrębność postaci. Za pomocą fizjonomicznego szkicu Nałkowska z jednej strony wskazuje na fizyczną skończoność cielesnych zdarzeń, z drugiej strony - co oczywiste - podkreśla ich osobliwość, wyjątkowość ${ }^{43}$. Z kolei historie chorób to tutaj historie cielesne w tym sensie, że ujęte niejednokrotnie w język medyczny nie wykraczają poza wiedzę konkretnej postaci, nie świadczą o żadnej nadwiedzy, rozgrywają się $\mathrm{w}$ granicach jednostkowego przeżywania choroby ${ }^{44}$. Obecne w tekście ciała nie przestają więc niepokoić, cielesność powiadamia o śmiertelności, świadczy o niej, wraz z odsłanianymi w powieści wątkami somatycznymi na chwilę uobecnia się to, co dane, lecz - jako się rzekło - niekoniecznie posiadające ukryte znaczenie.

Tymczasem w spojrzeniu młodego Mrowy w miejscach, gdzie ciało styka się ze światem, pojawia się potworność. W jego oczach graniczność (śmiertelność) ludzkiego ciała jest monstrualna w sposób, który domaga się, jak sadzę, rozwinięcia zasygnalizowanego powyżej wątku zuchwałości Jakuba. Kiedy bohater Niecierpliweych patrzy na spożywającego posiłek Modesta - wkładającego w siebie jedzenie niczym do worka - albo też kiedy odtwarza w swojej pamięci postać dziadka, odbierając lekcję anatomii, podczas której ciało zostaje bezwzględnie zredukowane do pojemnika wypełnionego narządami ${ }^{45}$, czyni nas świadkami nie tyle wtajemniczenia w naturę człowieka, ile kilku własnych, „narcystycznych” uwikłań. Wzrok Jakuba skierowany w stronę ciał innych jest dowodem na to, że młody Mrowa wszystko radykalnie subiektywizuje, a gdy w grę wchodzi

43 „Babka Ludwika siedziała na sztywnym krześle, nie w fotelu. Jej starość nie znała zwykłych akcesoriów ani ułatwień. Jej przymusowa nieruchomość, gdyż miała nogi bezwładne, wydawała się zwyczajnym odpoczynkiem. Poruszała szczękami, cienkie płatki warg chwiały się lekko nad pustym miejscem po zębach" (N, s. 89).

44 „Nieraz budziła się rano, oblana potem, ogłuszona sercem [...]. Była już przekonana, że głuchy, targający ból w dole brzucha z prawej strony - to zapalenia wyrostka robaczkowego. Czuła, że ma podwyższoną temperaturę, ale za nic nie chciała założyć termometru" (N, s. 76).

45 „Jakub widział rozkrojone zwierzęta, w atlasach anatomicznych obnażone narządy ludzkie - żołądek, wątrobę, zielonoszare przeguby jelit, gąbeczki gałęziste płuc. Czyżby to istotnie było nami? - myśłał ze zgrozą. Czy można na to przystać? Czy przyjąć tę poniżającą identyczność” (N, s. 109). 
obserwacja postaci kalekich - jakoś nawet zawłaszcza. Cudze kalectwo przemienia on przecież $\mathrm{w}$ metaforę tkwiącego $\mathrm{w}$ nim kalectwa wewnętrznego ${ }^{46}$.

W innym miejscu utworu Nałkowskiej za zasłoną wtajemniczenia w sekrety ludzkiej cielesności odkryć możemy warstwę opowieści o wstręcie. Sądzę, że bohater Niecierpliweych mógłby być bohaterem Potegi obrzydzenia Julii Kristevej ${ }^{47}$, zwłaszcza w związku z kwestiami odrazy do jedzenia jako odmowy zacierania granicy pomiędzy „ja” a nieczystością, dążenia do ustanowienia jednoznacznych opozycji wewnątrz - na zewnątrz, „ja” - inny ${ }^{48}$, ale także w związku z zagadnieniami, które autorka eseju odnosi do figury trupa jako „granicy kondycji żywej istoty”, granicy, jaką „permanentnie odsuwamy, żeby żyć” ${ }^{49}$. Jakub jest zuchwały w pragnieniu tego, co niemożliwe w pragnieniu wyjścia poza własne biologiczne, rozepchane trzewiami, skończone i śmiertelne ciało.

W tym kontekście zabójstwo Teodory i samobójstwo Jakuba nabiera fizjologicznej - nie zaś metafizycznej, ani też parabolicznej - ostrości i wprawdzie nie anuluje tragizmu postaci Mrowy, ale sprawia, że przestaje on być głównym, paradygmatycznym nosicielem tragiczności $\mathrm{w}$ powieści oraz pokazuje, że Nałkowska budując postać „niecierpliwego” bohatera, opowiada historię psychicznego zranienia, którego wpisanie w symboliczne sensy prowadzi do tragicznego rozwiązania. Co więcej, historia ta, ujęta w konwencję dramatu - nawet melodramatu - małżeńskiego prowokuje do tego, by w dynamice miłosnego związku dylematy Jakuba, jego miotanie się pomiędzy materialnością a transcendencją, odczytać w schemacie przypowieści o męskości zamkniętej w dialektycznym koszmarze, lub inaczej:

${ }_{46}$ Tłem dla „anatomii spojrzenia” bohatera powieści Nałkowskiej mogłyby być rozważania Merleau-Ponty'ego: „Czyjeś ciało jest przede mną - ale wiedzie osobliwy żywot [...]. W moich oczach ten drugi znajduje się zawsze na marginesie tego, co widzę i słyszę; jest po mojej stronie, jest u mego boku albo ze mną, nie ma go w tym miejscu, które moje spojrzenie miażdży i pozbawia wszelkiego «wnętrza»". M. Merleau-Ponty, Obecni w stowie, przeł. J. Skoczylas, w: Proza świata, wybór S. Cichowicz, Warszawa 1976, s. 65. 2007.

47 J. Kristeva, Potega obrzydzenia. Esej o wstręcie, przeł. M. Falski, Kraków

$4^{8}$ Ibidem, s. 7-33.

49 „Rana pełna krwi i ropy albo słodkawy i gryzący odór potu, nie oznaczają śmierci. W obliczu śmierci oznaczonej - na przykład płaskiego encefalogramu - zrozumiałabym, buntowałabym się lub z nią pogodziła. Nie, taki prawdziwy teatr, bez makijażu i bez maski, odpad oraz trup wskazują mi na to, co permanentnie odsuwam, żeby żyć. Te wydzieliny, ta nieczystość, to gówno w śmierci są tym, co życie znosi z wielkim trudem. Jestem tu na granicy swojej kondycji jako żywej istoty”. Ibidem, s. 9. 
koszmarnym ciągu prób znoszenia, przekraczania nieusuwalnych egzystencjalnych sprzeczności. Czy przemoc to tutaj rodzaj męskiego obłędu?

To pytanie-rozpoznanie mogłoby skomplikować rozważania jednej z badaczek, która odnalazła znaczące analogie pomiędzy powieścią Zofii Nałkowskiej a utworem Powrót Filipa Latinovicza autorstwa Miroslava Krležy $5^{\circ}$. Dla bohatera chorwackiego pisarza, jak zauważa Krystyna Jakowska, biologizm jest formą ataku na świat - w Niecierpliweych to, co biologiczne, zostaje podporządkowane problematyce egzystencjalnej ${ }^{5 \mathrm{I}}$. W moim przekonaniu Jakub nie przestaje być uwikłany w biologizm i agresję, a „autorsko przypieczętowana” problematyka egzystencjalna nie przylega, jak się zdaje, wprost do powieściowej kreacji Mrowy, stanowi dla niej raczej czytelny kontrapunkt. W jakiej mierze powieść Nałkowskiej była, jest polemiką z wizją Krležy jako autora i byłego kochanka pisarki? To pytanie retoryczne, lecz interesujące, bo wskazuje - być może - na autobiograficzne podłoże romansowego wątku Niecierpliweych, a także uświadamia, że Nałkowskiej mogło zależeć na stworzeniu opowieści, która uwypuklałaby „anatomię” męskiej przemocy poza przekonaniem o jej naturalistycznej nieredukowalności.

Nieodrębność Jakuba od świata zgodnie z intencjami narratorki budzi empatię, ale kiedy jego rozpacz zagarnia powieściowy świat, wszystko - „genetyczna klątwa”, rodzinne kompleksy, poczucie winy, wyrzuty sumienia - staje się paradoksalnym usprawiedliwieniem jego zbrodni. Jeśliby pamiętać o Nałkowskiej jako czytelniczce Nietzschego, to bohater Niecierpliweych okaże się ofiarą resentymentu, a w całej tej powieści o utracie i śmierci kilka fragmentów wybrzmi zdumiewająco - bardzo afirmatywnie. Na przykład to, co wydarza się po śmierci Ludwiki. Paulina i Marta przygotowują ciało zmarłej, by móc ułożyć je w trumnie. Zadziwione po raz pierwszy ujrzaną nagością matki z troską pielęgnują wszystkie jej cielesne niedoskonałości, skwapliwie dopełniają ostatniego rytuału, by w końcu z samego środka rozpaczy zobaczyć w martwej Ludwice piękno i dostojność, a potem żałować, że nie mogli tego dostrzec inni, zanim jej ciało znalazło się w kaplicy ${ }^{52}$.

5० K. Jakowska, Natkowska i Krleža, czyli jeszcze o „Niecierpliwych”, „Ruch Literacki” 2006, z. 3, s. 367-375.

${ }^{51}$ Ibidem, s. 369.

$5^{2}$ „Później zaplotły jej ręce palcami, na piersiach położyły dość duży niklowy krzyż z Chrystusem i podziwiały ją, że tak pięknie wygląda [...]. Marta i Paulina zapragnęły nagle, żeby ją więcej ludzi zobaczyło, żałowały, że nie zawiadomiły nikogo z rodziny stryja Tytusa. Nawet Teodora jej nie widziała” (N, s. 111). 
Najbliższa "tragicznej afirmacji” ${ }_{53}$ jest jednak Teodora. Żona Jakuba, jak wszyscy bohaterowie Niecierpliwyych, żyje blisko śmierci. Obok życiowej miotaniny Mrowy, ustanawiającego pomiędzy sobą a innymi zabójczą zależność, Nałkowska „przemyca” opowieść o kobiecym pragnieniu, którego nie unieważnia trwałe istnienie rozpaczy. Podczas wiosennego pobytu w Wiekszni Teodora nosi w sobie ból, poczucie niespełnienia, ale też w niejasny sposób przyjemny lęk przed powabem Piotra i przez chwilę absolutnie bezstroskie dążenie do bliskości - najpierw z Albinem, potem $\mathrm{z}$ Jarosławem. Jest $\mathrm{w}$ niej zatem daremność, ale i wibrująca chęć życia, energia pożądania. W przeciwieństwie do Jakuba Teodora w sprzecznościach i ambiwalencjach nie dostrzega wyłącznie ciemności, w zarażonej śmiercią powieści jest ona tą postacią, która na moment - nie godząc egzystencjalnych sprzeczności za wszelka cenę - rozbłyskuje. W związku z wydarzeniami późniejszymi zyskujemy pewność, że to nie postać Jakuba odbija kondycję narratorki. Z drugiej strony - zyskujemy również niepewność co do tego, czy mamy do czynienia z tekstem opowiadającym o cierpiącym Morwie, czy z utworem opisującym próbę ucieczki przed jego okrucieństwem.

Teraz wszyscy zatrzymali się przy innym stawie, gdzie zachlapani wodą, umazani błotem ludzie ważyli ryby. Sortowali je w dwóch szufladach, przesuwali po dnie z dziurkowanej blachy, przekładali do balii. Dwa kaczery na długich kijach, niby ogromne sieci na motyle, wyławiały z magazynów i donosiły wciąż nowy materiał do skrzyń. W okach siatki zostawały drobne ryby, uplątane płetwami i skrzelami, trzepotały się w błękitnym powietrzu jak ptaki. Strząśnięte spadały na ziemię i tam pod nogami robotników trzepotały się dalej i podskakiwały niezmordowane, przez nikogo nie brane pod uwagę. Spośród robotników wyszedł Albin. Przystanął i popatrzył na Jakuba. Teodora obejrzała się i cofnęła w popłochu.

- Uważaj - powiedział Jarosław, przytrzymując ją za łokieć.

Teodora znowu zacisnęła na piersiach swoją chustkę.

Albin trzymał w ręku małą rybę. Podszedł do Pii i pokazał, że ma takie ostre płetwy po obu stronach grzbietu, jak brzytwy. - O!

- To szkodnik - powiedział. - Przepłynie tylko pod karpia i cały brzuch mu rozpruje.

Trzymał rybę, lekko ściskając w palcach jej ostre płetwy, żeby ją lepiej zobaczyli.

53 „Tragiczność jest afirmacją, bo afirmacja afirmuje przypadek, a w przypadku konieczność, bo afirmuje stawanie się, a w stawaniu byt, bo afirmuje wielość, a w wielości jedno. Tragiczność jest rzutem kości”. G. Deleuze, Tragiczność, w: idem, Nietzsche i filozofia, przeł., posłowie B. Banasiak, Warszawa 1993, s. 42. 
$[\ldots]$

Jakub patrzył na tępy pysk ryby, na jej otwarte małe okrąłe oczy i nie dotkną jej. Unieruchomiona palcami człowieka tkwiła w powietrzu sztywno, jakby w natężonym oczekiwaniu.

- Szkodnik - powtórzył Albin i ścisnął ze sobą obie twarde płetwy tak, że wyłamały się z chrzęstem.

Teodora patrząca $\mathrm{w}$ tę stronę krzyknęła. Jarosław się roześmiał. Albin rzucił rybę daleko na groblę $\mathrm{w}$ trawę. - No, no - mruknął Jakub. (N, s. 228)

W tej okrutnej i zarazem znakomitej scenie powieści cielesny opór Teodory nie został zapisany przez pisarkę mimochodem. Zaciśnięta przez bohaterkę na piersiach chustka jest niemal niewidoczna, lecz znacząco przecina przestrzeń wyznaczaną przez ciała Albina, Jarosława i Jakuba, męskie ciała wypełnione oczywistą przemocą. Czy Niecierpliwei mogą być opowieścią o lęku przed tą oczywistością?

\section{ARleta Galant}

\section{The King's Death and Theodora's Shawl}

The author interprets two novels by Zofia Nałkowska - Węzly zycia [The Bonds of Life] and Niecierpliwi [The Impatient]. In a hermeneuticfeminist analysis of selected figures and motifs, the article presents new meanings of concepts that are crucial for the understanding of anthropology of corporeality in Nałkowska's writing project. Among the focal points of the discussion there are the dignity of "lay bodies," as well as "male" and "female" fantasies of violence.

Keywords: body, violence, dignity, Zofia Nałkowska's writing project.

Arleta Galant - doktor, literaturoznawczyni, krytyczka literacka, adiunkt w Zakładzie Literatury Polskiej XX Wieku Instytutu Polonistyki i Kulturoznawstwa US. W latach 2004 i 2006 wykładowczyni Gender Studies w Instytucie Stosowanych Nauk Społecznych UW. Autorka książek Prywatne, publiczne, autobiograficzne. O dziennikach i esejach Jana Lechonia, Zofii Natkowskiej, Marii Kuncewiczowej i Jerzego Stempowskiego (2010) oraz Prowincje literatury. Polska proza kobiet po 1956 r. (w przygotowaniu). Współredaktorka (z Ingą Iwasiów) tomów Dwadzieścia lat literatury polskiej. Idee, ideologie, metodologie (2008) oraz Pisarstwo kobiet pomiędzy dwoma dwudziestoleciami (2011). Od 1999 do 2012 r. stała współpracowniczka Szczecińskiego Dwumiesięcznika Kulturalnego „Pogranicza”, autorka szkiców i recenzji publikowanych na łamach między innymi: „Ruchu Literackiego”, „Societas/ Communitas”, „Twórczości”, „FA-artu”, „Opcji”, „Tygodnika Powszechnego", „Zadry”. 